ROZDZIAŁ 7

\title{
Rewitalizacja a akcesja Polski do Unii Europejskiej
}

\subsection{Wykorzystanie funduszy strukturalnych $\mathrm{UE} w$ rewitalizacji}

Wejście Polski do Unii Europejskiej otworzyło możliwość wykorzystywania funduszy strukturalnych UE także dla potrzeb rewitalizacji. Zadaniem funduszy strukturalnych jest wspieranie finansowe restrukturyzacji i modernizacji gospodarek krajów unijnych, dla uzyskania większej spójności ekonomicznej i społecznej krajów należących do UE. Wsparcie kierowane jest do tych regionów i sektorów gospodarki, które bez zewnętrznej pomocy finansowej nie są w stanie osiagnać średniego poziomu ekonomicznego w UE.

W bieżącej siedmiolatce 2007-2013 Unia Europejska wspomaga finansowo projekty rewitalizacji zdegradowanych terenów miejskich, terenów poprzemysłowych oraz humanizacji blokowych osiedli wielorodzinnych w ramach ERDF (European Regional Development Fund) czyli Europejskiego Funduszu Rozwoju Regionalnego oraz ESF (European Social Fund) czyli Europejskiego Funduszu Społecznego.

Z Europejskiego Funduszu Rozwoju Regionalnego realizowane są przede wszystkim zadania tzw. „twarde” - infrastrukturalne, natomiast Europejski Fundusz Społeczny służy finansowaniu zadań tzw. „miękkich” - społecznych.

Podstawowym warunkiem możliwości starania się władz lokalnych o środki finansowe funduszy strukturalnych na cele rewitalizacji jest opracowanie Lokalnego Programu Rewitalizacji. Proponowany schemat struktury takiego programu dla zdegradowanych obszarów miejskich oraz obszarów poprzemysłowych i powojskowych został przedstawiony w Uzupełnieniu Zintegrowanego Programu Rozwoju Regionalnego ZPORR 2004-2006 ${ }^{1}$. W sytuacji braku dokumentów prawnych na szczeblu krajowym regulujących proces tworzenia i wdrażania programów rewitalizacji, ten właśnie dokument $\mathrm{w}$ pewnym sensie wypełniał lukę legislacyjną i podawał w sposób ujednolicony założenia, jakie należy przyjąć przy opracowywaniu Lokalnych Programów Rewitalizacji.

Jak pisze, w ramach opracowania podsumowującego grant badawczy zamawiany dotyczący rewitalizacji miast polskich, Alina Muzioł-Wencławowicz,

${ }^{1}$ Uzupetnienie Zintegrowanego Programu Rozwoju Regionalnego ZPORR 2004-2006 (tekst jednolity uwzględniający zmiany przyjęte przez Komitet Monitorujący ZPORR w dniu 17 stycznia 2007 r. $^{1}$ ), DzU z 30 maja 2006 r., nr 102, poz. 706. 
Najdalej idącą próbą normowania metodologii i pojęć z tego zakresu (rewitalizacji) były wytyczne dla lokalnych programów rewitalizacji zawarte w Uzupetnieniu Zintegrowanego Programu Operacyjnego Rozwoju Regionalnego ZPORR 2004-2006. Trwałość tej (nawet jeśli niedoskonałej) regulacji nie została utrzymana w dokumentach programowych na lata 2007-2013, co przede wszystkim podważyło ciągłość programowania i stanowiło o upośledzeniu przeprowadzonych wcześniej procedur konsultacyjnych i decyzyjnych względem programowania dla potrzeb funduszy strukturalnych ${ }^{2}$.

Przeprowadzone przez Instytut Rozwoju Miast wspomniane wyżej badania ujawniły zjawisko bardzo niepokojące: w wielu miastach polskich opracowanie Lokalnych Programów Rewitalizacji stało się jedynie narzędziem służącym pozyskaniu funduszy strukturalnych UE przeznaczonych na rewitalizację - czyli środek mający służyć realizacji celu, jakim była realizacja programu rewitalizacji, stał się celem samym w sobie. Należy przypuszczać, że tak wąskotorowe wykorzystanie tych opracowań wynika przede wszystkim z braku wyspecjalizowanych struktur organizacyjnych służących wdrażaniu rewitalizacji, w związ$\mathrm{ku} \mathrm{z}$ czym pozyskiwanie funduszy unijnych na cele rewitalizacji stanowi podstawowy i jedyny w zasadzie możliwy (a w każdym bądź razie najłatwiej osiągalny) do osiagnięcia w chwili obecnej cel działania samorządów.

7.2. Pierwszy okres programowania po przystąpieniu Polski do UE. Zintegrowany Program Operacyjny Rozwoju Regionalnego 2004-2006

\subsubsection{Działania związane z rewitalizacją miejskich obszarów zdegradowanych określone w ZPORR}

Cele i zasady udzielania pomocy finansowej Unii Europejskiej w ramach Europejskiego Funduszu Rozwoju Regionalnego oraz Europejskiego Funduszu Społecznego określone zostały w Zintegrowanym Programie Operacyjnym Rozwoju Regionalnego 2004-2006, zarządzanym na poziomie krajowym, a wdrażanym na poziomie poszczególnych województw ${ }^{3}$. Jak wspomniano wyżej, dokument ten w sytuacji braku uregulowań legislacyjnych dotyczących opracowania i wdrażania programów rewitalizacji, był istotnym źródłem informacji w sposobie tworzenia struktury programu rewitalizacji oraz działań, jakie można w nich zaproponować, aby uzyskały one możliwość wsparcia finansowego UE. Szczegółowe wytyczne dla potencjalnych beneficjentów, w tym propozycje struktury dokumentów Lokalnych Programów Rewitalizacji dotyczących rewitalizacji zdegradowanych obszarów miejskich, jak i obszarów poprzemy-

${ }^{2}$ A. Muzioł-Wencławowicz, Rewitalizacja dzielnic śródmiejskich, [w:] W. Jarczewski (red.), Przestrzenne aspekty rewitalizacji - śródmieścia, blokowiska, tereny poprzemystowe, pokolejowe i powojskowe, seria: Rewitalizacja Miast Polskich, t. 4, Kraków 2009.

${ }^{3} \mathrm{http}: / / w w w . f u n d u s z e s t r u k t u r a l n e . g o v . p l, 11.2009$. 
słowych i powojskowych, znalazły się w Uzupełnieniu Zintegrowanego Programu Operacyjnego Rozwoju Regionalnego ZPORR 2004-2006. Ministerstwo Gospodarki i Pracy wydało także Podręcznik procedur wdrażania Zintegrowanego Programu Operacyjnego Rozwoju Regionalnego ${ }^{4}$ oraz Przewodnik dotyczqcy kryteriów planowania oraz zarzqdzania projektami dotyczqcymi rewitalizacji zdegradowanych obszarów miejskich, poprzemystowych i powojskowych w ramach Zintegrowanego Programu Operacyjnego Rozwoju Regionalnego, finansowanego ze środków Funduszy Strukturalnych ${ }^{5}$, w celu wspomagania beneficjentów w tworzeniu dokumentów programów rewitalizacji w sposób spełniający wymagania określone w ZPORR.

[...] Głównym celem Zintegrowanego Programu Operacyjnego Rozwoju Regionalnego było tworzenie warunków wzrostu konkurencyjności regionów oraz przeciwdziałanie marginalizacji niektórych obszarów w taki sposób, aby sprzyjać długofalowemu rozwojowi gospodarczemu kraju, jego spójności ekonomicznej, społecznej i terytorialnej oraz integracji z Unią Europejską (UE). Wzrost konkurencyjności należy rozumieć jako oddziaływanie na zmiany struktury gospodarczej i poprawę sytuacji wszystkich regionów w Polsce względem regionów europejskich, w zakresie produktywności gospodarki, wydajności pracy, tworzenia i absorpcji innowacji, wykształcenia mieszkańców, dochodów ludności oraz ilości i jakości infrastruktury technicznej, a więc tych czynników, które decydują obecnie o sile gospodarek państw i regionów. Przeciwdziałanie marginalizacji niektórych obszarów należy rozumieć jako podjęcie działań interwencyjnych w ograniczonej liczebnie i przestrzennie grupie obszarów wiejskich, podlegających restrukturyzacji oraz degradacji społeczno-ekonomicznej, przestrzeni miejskiej, poprzemysłowej i powojskowej, o najmniejszych możliwościach rozwojowych oraz najtrudniejszej sytuacji społeczno-gospodarczej ${ }^{6}$.

Przeciwdziałaniu marginalizacji obszarów miejskich służyć ma właśnie rewitalizacja zdegradowanych obszarów miejskich i poprzemysłowych.

Działania związane $\mathrm{z}$ procesem rewitalizacji przewidziane były w ramach Priorytetu: 3 Rozwój lokalny, Działanie: 3.3. Zdegradowane obszary miejskie, poprzemystowe i powojskowe. Adresowane były one do władz zdegradowanych miast i dzielnic miast, terenów poprzemysłowych i powojskowych, w zgodzie z opracowanymi dla tych obszarów planami rozwoju lokalnego i programami rewitalizacji. Jak podkreślono $\mathrm{w}$ opisie Działania 3.3., podstawową cechą

\footnotetext{
${ }^{4}$ Podręcznik procedur wdrażania Zintegrowanego Programu Operacyjnego Rozwoju Regionalnego, Ministerstwo Gospodarki i Pracy, Warszawa 2004.

${ }_{5}$ Przewodnik dotyczqcy kryteriów planowania oraz zarzqdzania projektami dotyczacymi rewitalizacji zdegradowanych obszarów miejskich, po-przemysłowych i po-wojskowych w ramach Zintegrowanego Programu Operacyjnego Rozwoju Regionalnego, finansowanego ze środków Funduszy Strukturalnych, Warszawa 2004.

${ }^{6}$ Uzupetnienie Zintegrowanego Programu Operacyjnego Rozwoju Regionalnego ZPORR na lata 2004-2006 (tekst jednolity uwzględniający zmiany przyjęte przez Komitet Monitorujący ZPORR w dniu 17 stycznia 2007 r. ${ }^{1}$ ), DzU z 30 maja 2006 r., nr 102, poz. 706.
} 
programów rewitalizacji powinna być ich kompleksowość, umożliwiająca rozwiązywanie zarówno problemów infrastrukturalnych, społecznych, jak i gospodarczych. Dlatego też projekty z zakresu poprawy stanu środowiska miejskiego, ładu przestrzennego, infrastruktury technicznej, wykorzystania dziedzictwa kulturowego i modernizacji zasobów budowlanych powinny być wdrażane w powiązaniu z projektami z zakresu pobudzania ożywienia gospodarczego oraz rozwiązywania problemów społecznych.

W opisie Działania 3.3. podkreślono konieczność opracowania przez miasta wieloletnich Lokalnych Programów Rewitalizacji w celu możliwości ubiegania się o wsparcie finansowe UE. W programach należało wyznaczyć - na bazie podanych kryteriów identyfikacji obszarów kryzysowych ${ }^{7}$ - obszary poddawane rewitalizacji.

Określono również grupę beneficjentów końcowych:

- władze samorządowe gminy lub miasta na prawach powiatu,

- podmioty, których projekt został ujęty w Lokalnym Programie Rewitalizacji: spółki prawa handlowego oraz inne jednostki organizacyjne nie działające w celu osiagnięcia zysku lub przeznaczające zyski na cele statutowe, w których większość udziałów lub akcji posiadają podmioty wymienione w pkt. 1 lub samorząd województwa,

- spółdzielnie mieszkaniowe,

- jednostki zaliczane do sektora finansów publicznych, w szczególności policja, straż pożarna, szkoły wyższe oraz

- wspólnoty mieszkaniowe.

Zadania w zakresie odnowy zasobów materialnych w obszarze rewitalizacji obejmowały: remonty, modernizację infrastruktury technicznej, poprawę funkcjonalności ruchu kołowego i pieszego, podniesienie estetyki i poprawę wyposażenia przestrzeni publicznej, renowację obiektów wartościowych pod względem historycznym i architektonicznym.

Projekty z zakresu problematyki społecznej wiązały się z działaniami na rzecz walki z patologiami społecznymi oraz przeciwdziałaniu zjawisku wykluczenia społecznego, w tym organizacją kursów, szkoleń i innych różnorodnych form kształcenia i podnoszenia kwalifikacji zawodowych, ułatwiających osobom bezrobotnym lub zagrożonym bezrobociem dostęp do rynku miejsc pracy.

W odniesieniu do aspektów gospodarczych przewidziano działania zmierzające do tworzenia warunków lokalowych i infrastrukturalnych wspierających rozwój małej i średniej przedsiębiorczości. Na wsparcie mogły również liczyć projekty dotyczące przebudowy lub remontów i adaptacji obiektów infrastruktu-

\footnotetext{
${ }^{7}$ Kryteria identyfikacji obszarów kryzysowych przedstawiono w rozdz. 2.4.
} 
ry publicznej na cele związane z rozwojem funkcji rekreacyjnych, kulturalnych i sportowych, powiązanych z działalnością gospodarczą. Istotnym elementem zwiększania atrakcyjności inwestycyjnej rejonów zdegradowanych były również działania z zakresu podnoszenia poziomu bezpieczeństwa i zapobiegania przestępczości w obszarach zagrożonych patologiami społecznymi.

\subsubsection{Program Rewitalizacji Obszarów Miejskich ${ }^{8}$}

W aneksie do Uzupełnienia Zintegrowanego Programu Operacyjnego Rozwoju Regionalnego 2004-2006 przedstawiono propozycję struktury miejskiego programu rewitalizacji oraz programu rewitalizacji obszarów poprzemysłowych i powojskowych. Proponowana struktura może także obecnie - w kolejnym okresie programowania UE - służyć po pewnych niewielkich modyfikacjach jako model opracowania programu rewitalizacji dla zdegradowanych obszarów miejskich. Dokument ten powinien zawierać następujące zasadnicze części:

I. Charakterystyka obecnej sytuacji w mieście - w podziale na sferę przestrzenną (granice stref konserwatorskich, ochrona środowiska, własność gruntów i budynków, infrastruktura techniczna), społeczną (struktura społeczna i demograficzna, identyfikacja grup społecznych wymagających wsparcia, dochody gospodarstw domowych, struktura organizacji pozarządowych) i gospodarczą (główni pracodawcy, struktura podstawowych branż gospodarki, liczba podmiotów gospodarczych w poszczególnych sektorach); podsumowanie w postaci analizy SWOT

II. Nawiązanie do strategicznych dokumentów dotyczących rozwoju przestrzenno-społeczno-gospodarczego miasta i regionu, takich jak: Strategia Rozwoju Województwa, Strategia Rozwoju Gospodarczego Gminy, Studium uwarunkowań i kierunków zagospodarowania przestrzennego Gminy, dokumenty dotyczące polityki sektorowej, miejscowe plany zagospodarowania przestrzennego w obszarach objętych rewitalizacją.

III. Założenia programu rewitalizacji: zasięg terytorialny rewitalizowanego obszaru i uzasadnienie jego wyboru, określenie etapowania programu rewitalizacji, wyznaczenie projektów i zadań inwestycyjnych, kryteria wyboru pilotażu i kolejność realizacji, oczekiwane wskaźniki osiagnięć.

IV. Planowane dzialania, m.in. w zakresie: rozwoju infrastruktury technicznej, rozwoju transportu, restrukturyzacji przemysłu, remontów i renowacji istniejących zasobów mieszkaniowych, budowy nowych mieszkań, rozwoju infrastruktury społecznej, kulturalnej i turystycznej, wspierania przedsiębiorczości, rozwoju turystyki, uruchamiania finansowych mechanizmów wsparcia

\footnotetext{
${ }^{8}$ Uzupetnienie Zintegrowanego...
} 
rewitalizacji, rozwoju MŚP, rozwoju zasobów ludzkich, przeciwdziałania wykluczeniu społecznemu, walki z patologiami społecznymi, tworzenia równych szans, zapobiegania zjawisku bezrobocia i bezdomności, uruchamiania systemu grantów dla organizacji pozarządowych.

V. Plan finansowy realizacji rewitalizacji: w podziale na środki pochodzące z budżetu JST, budżetu państwa, środki prywatne, środki UE i inne.

VI. System zarządzania i wdrażania: opisujący proponowany system zarządzania programem.

VII. Sposoby monitorowania, oceny i komunikacji społecznej.

\subsection{Narodowe Strategiczne Ramy Odniesienia 2007-2013}

W bieżącej siedmiolatce programowania Unii Europejskiej dokumentem strategicznym określającym priorytety i obszary wykorzystania oraz system wdrażania funduszy unijnych: Europejskiego Funduszu Rozwoju Regionalnego (EFRR), Europejskiego Funduszu Społecznego (EFS) oraz Funduszu Spójności, jest dokument pod tytułem: Narodowe Strategiczne Ramy Odniesienia 20072013. Narodowa Strategia Spójności (NSS) ${ }^{9}$.

Dokument ten formułuje cel strategiczny rozwoju społeczno-gospodarczego na poziomie krajowym, którym jest tworzenie warunków do wzrostu konkurencyjności gospodarki polskiej opartej na wiedzy i przedsiębiorczości, zapewniającej wzrost zatrudnienia oraz wzrost poziomu spójności społecznej, gospodarczej i przestrzennej.

Do realizacji celu strategicznego ma przyczynić się wdrażanie sześciu celów szczegółowych:

1. Poprawa jakości funkcjonowania instytucji publicznych oraz rozbudowa mechanizmów partnerstwa.

2. Poprawa jakości kapitału ludzkiego i zwiększenie spójności społecznej.

3. Budowa i modernizacja infrastruktury technicznej i społecznej mającej podstawowe znaczenie dla wzrostu konkurencyjności Polski.

4. Podniesienie konkurencyjności i innowacyjności przedsiębiorstw, w tym szczególnie sektora wytwórczego o wysokiej wartości dodanej oraz rozwój sektora usług.

5. Wzrost konkurencyjności polskich regionów i przeciwdziałanie ich marginalizacji społecznej, gospodarczej i przestrzennej.

${ }^{9}$ Polska. Narodowe Strategiczne Ramy Odniesienia 2007-2013 wspierajace wzrost gospodarczy $i$ zatrudnienie. Narodowa Strategia Spójności, Ministerstwo Rozwoju Regionalnego, Warszawa 2007. 
6. Wyrównywanie szans rozwojowych i wspomaganie zmian strukturalnych na obszarach wiejskich ${ }^{10}$.

Problematyka rewitalizacji obszarów zdegradowanych została ujęta w Celu szczegółowym 5: Wzrost konkurencyjności polskich regionów i przeciwdziatanie ich marginalizacji społecznej, gospodarczej $i$ przestrzennej, gdzie określono zasady przeciwdziałania marginalizacji i peryferyzacji obszarów problemowych.

W omawianym dokumencie pojawiła się nowa definicja rewitalizacji, obejmująca większy niż $\mathrm{w}$ poprzednim okresie programowania UE zakres problemowy. Poza podejmowanymi także dotychczas kwestiami związanymi z działaniami na rzecz przemian przestrzennych, społecznych i gospodarczych, prowadzących do poprawy jakości życia, poziomu ładu przestrzennego i ożywienia ekonomicznego w zdegradowanych częściach miast, w tym często $\mathrm{w}$ rejonach starej, zabytkowej zabudowy, do zadań z zakresu rewitalizacji zaliczono także humanizację osiedli mieszkaniowych $\mathrm{z}$ wielkiej płyty.

Jako jeden z zasadniczych celów rewitalizacji wymieniono zachowanie walorów historycznych, w tym przede wszystkim urbanistycznych i architektonicznych, dla podkreślenia walorów ich indywidualności, a w rezultacie dla zwiększenia atrakcyjności turystycznej, a co za tym idzie - wzrostu szans rozwojowych. W obszarach zagrożonym wykluczeniem społecznym proces rewitalizacji musi łączyć działania techniczne $\mathrm{z}$ działaniami na rzecz rozwoju społecznego i gospodarczego.

Cele Narodowej Strategii Spójności realizowane będą na poziomie regionalnym za pomocą 16 programów regionalnych, w ramach wykorzystywania środków EFRR. Fundusze EFS będą rozdysponowywane przez Ministerstwo Rozwoju Regionalnego w ramach programu operacyjnego Kapitat Ludzki.

\subsection{Regionalny Program Operacyjny Województwa Lódzkiego 2007-2013 ${ }^{11}$}

Regionalny Program Operacyjny Województwa Łódzkiego 2007-2013 określa główne kierunki rozwoju województwa, w tym dążenie do poprawy konkurencyjności gospodarczej, promowanie rozwoju zrównoważonego oraz zapewnienie większej spójności społecznej, ekonomicznej i przestrzennej regionu.

Realizacji założonych celów ma służyć wdrażanie siedmiu osi priorytetowych:

1. infrastruktura transportowa,

2. ochrona środowiska,

\footnotetext{
${ }^{10}$ Tamże, s. 68.

${ }^{11} \mathrm{http} / / / w w w . l o d z k i e . p l, 11.2009$.
} 
3. gospodarka, innowacyjność, przedsiębiorczość,

4. społeczeństwo informacyjne,

5. infrastruktura społeczna,

6. odnowa obszarów miejskich,

7. pomoc techniczna.

Odnowa i rewitalizacja zdegradowanych obszarów miejskich (oś priorytetowa 6) została uznana za bardzo ważny element przyczyniający się do realizacji założonego celu strategicznego Regionalnego Programu Operacyjnego, a także do osiagnięcia celu szczegółowego: ożywienia gospodarczego i społecznego na terenach zdegradowanych w obszarach miejskich. Realizacja działań rewitalizacyjnych pozwoli na doprowadzenie do ożywienia gospodarczego $\mathrm{w}$ rejonach problemowych, odbudowy więzi społecznych oraz przyczyni się do zapobiegania występowaniu zjawisk patologicznych, doprowadzając w efekcie do zwiększenia spójności tych obszarów z pozostałymi rejonami.

Podkreślono konieczność rewitalizacji dziedzictwa historycznego, w tym architektonicznego, miast regionu łódzkiego, w celu utrzymania wyjątkowego w skali kraju charakteru wielu miast.

Dla realizacji wspomnianego wcześniej celu szczegółowego przewidziano następujące cele operacyjne:

- rewitalizacja substancji architektonicznej terenów i obiektów poprzemysłowych i powojskowych,

- zwiększenie atrakcyjności obszarów miejskich dla inwestorów lokalnych i zewnętrznych,

- odnowa zdegradowanych dzielnic mieszkaniowych, w tym rewitalizacja substancji mieszkaniowej.

Ostatni z wymienionych celów szczegółowych stanowi novum w stosunku do poprzedniego okresu wdrażania programów rewitalizacji w latach 2004 2006, odzwierciedlając zmianę polityki Unii w stosunku do rewitalizacji zasobów mieszkaniowych ${ }^{12}$. Zadania realizowane w jego ramach polegać mają na modernizacji i odbudowie oraz adaptacji obiektów w zdegradowanych obszarach miejskich, osiedlach mieszkaniowych i terenach poprzemysłowych do nowych funkcji gospodarczych, społecznych, edukacyjnych, kulturalnych, rekreacyjnych i turystycznych, zarazem prowadząc do tworzenia nowych, stałych miejsc pracy oraz neutralizacji niekorzystnych zjawisk społecznych, gospodarczych i ekologicznych.

${ }^{12} \mathrm{~W}$ obecnym okresie planowania UE uwzględniono liczne postulaty płynące ze strony krajów członkowskich i uwzględniono potrzebę włączenia w listę zadań związanych z rewitalizacją także odnowę zasobów mieszkaniowych, które stanowią podstawowe tworzywo ilościowe budowlanej tkanki miasta. 
$\mathrm{Na}$ wparcie finansowe mogą liczyć także projekty z zakresu kompleksowego zagospodarowania przestrzeni publicznych, podnoszenia bezpieczeństwa przeciwpożarowego i przeciwwłamaniowego budynków i obiektów oraz zapobiegania przestępczości $\mathrm{w}$ terenach rewitalizowanych, m.in. poprzez tworzenie systemów monitoringu służących poprawie poziomu bezpieczeństwa publicznego. Podkreśla się konieczność uwzględniania wymiaru społecznego we wszystkich planowanych działaniach infrastrukturalnych.

Instytucje, które mogą ubiegać się o przyznanie pmocy finansowej, to: jednostki samorządu terytorialnego (JST), ich związki i stowarzyszenia, jednostki organizacyjne JST posiadające osobowość prawną, partnerzy społeczni i gospodarczy JST, organizacje pozarządowe, kościoły i związki wyznaniowe, spółdzielnie i wspólnoty mieszkaniowe TBS oraz przedsiębiorcy. 